\title{
Yoke of corporate governance and firm performance: A study of listed firms in Pakistan
}

\author{
Amjad Ali1,2, Wajid Alim², Jawad Ahmed'2, Sabahat Nisar ${ }^{2}$ \\ ${ }^{1}$ European School of Administration and Management, France, ${ }^{2}$ Lahore School of Accountancy and Finance, University \\ of Lahore City Campus, Lahore, Pakistan
}

\begin{abstract}
Purpose: The objective of this exploration is to show the relation among corporate governance tools (i.e. board size, board independence, CEO status, Board Education, and Established Years of the firm) and firm performance, which in turn, is determined by return on asset (ROA). Methodology: We used quantitative data to discover the association between the variables. We considered top 75 companies registered on the Pakistan Stock Exchange in the period from 2010 to 2019. Findings: We found that there is a connection between firm performance with the overall extent of directors, board independence, and average education of board representatives. However, we observed insignificant results in terms of CEO duality and established years of the firm. The results predicted that an increase in the total number of board members, along with their education would enhance firm performance (ROA). On the other hand, reduction in board independence would reduce firm performance (ROA), which effectively explains the importance of corporate governance for the success of a firm's performance. Originality of the Study: Unlike previous studies, this study tried to find a long-term influence of corporate governance on firm performance by analyzing five different variables for the listed firms of Pakistan. Implication of the Study: The study highlights the importance of corporate governance tools, along with their effectiveness for the success of organizations in Pakistan.
\end{abstract}

Key words: Board education, board independence, board size, CEO duality, corporate governance, firm performance, Pakistan, return on asset

JEL Classification: G3: Corporate Finance and Governance: G30

\section{INTRODUCTION}

Corporate governance is the procedure and relation managed by numerous groups to manage and run a business (Cadbury Committee, 1992). Corporate governance has to turn out to be a prevalent debate in the growing economies. The general view is that implementation of corporate governance improves firm performance, and safeguards the shareholders' interests (Switzer and Tahaoglu, 2015). Corporate governance is thereby necessary to ease differences of opinion among the stakeholders, especially shareholders and executives, so that a firm's performance can be improved. Importantly, the implementation of corporate governance is different in every country because of its economic, political, and other local structures (Chan and Cheung, 2012). By

*Corresponding author:

Jawad Ahmed, Lahore School of Accountancy and Finance, University of Lahore City Campus, Lahore, Pakistan. E-mail: jawad.ahmed14@hotmail.com

Received: October 08, 2021; Accepted: November 20, 2021

DOI: $10.18843 / \mathrm{ijcms} / \mathrm{v} 13 \mathrm{i} 1 / 02$ 
and large, most businesses are inherited, and serve as the building blocks for an economy (Zellweger, 2017). According to Daily and Dalton (1997a), stock exchange listed businesses are the backbone of an economy, and the overall stock exchange results reflect the growth or decline of the economy. Miller and Breton-Miller (2006) found that firms run better, when they have the aim to lead business for the next generations; and in order to achieve this vision, they must follow certain frameworks. For example, in developed countries, firms work under wellmanaged regulatory frameworks. However, in developing countries like Pakistan, political instability and economic crises significantly affect the implementation of such frameworks.

Listed corporations of Pakistan are an important pillar of the economy and are operated under Pakistan corporate governance act that was established in 2002. Many businesses started implementing corporate governance acts in their firms (Hussain and Safdar, 2018); but, these corporations are either ignorant of the principle of corporate governance, or do not want to focus on the same (Jan et al., 2021). Although corporate governance has been discussed worldwide in many ways, there have been inadequate studies focused on Pakistan. Therefore, the goal of this research is to plug this gap in literature, and explore how firm performance of listed companies in Pakistan could be improved.

\section{LITERATURE REVIEW}

Most of the world's leading organizations are listed firms (Casillas and Pastor, 2015). Corporate governance features are inclined by law, opening up opportunities for new investors (Houcine et al., 2021). In the non-presence of a defined structure, investors find it difficult to know about their investments. Furthermore, it makes it easy for internal management to find flaws for misusing assets, which affect the shareholders' wealth and firm performance. A strong link is found between corporate governance and firm performance (Sami et al., 2011). According to Shaheen and Nishat (2005), corporations that do not follow corporate governance procedures, usually bear the loss in terms of their desired profits. The authors also stated that firms with no or fewer corporate governance practices achieve fewer financial advantages. Nandelstadh and Rosenberg, (2003) believed that firms with competent corporate governance procedures pay high value to the investors. Corporate governance also improves environmental performance (Khan and Johl, 2019; Toha et al., 2020), reporting (Khan et al., 2021) firm innovation ability (Khan and Johl, 2020), and addressing the stakeholders.

In addition, corporate governance procedures address every sector within the organization, setting a rule to improve the functional capabilities. The goal of every organization is to increase the shareholders' wealth (Gompers et al., 2003), and to do so, corporate governance processes need to be adhered to.

Internationally, there has been plenty of research on this topic, but empirical evidence does vary from one country to another. Thus, the results of these studies have never been consistent.

For instance, according to one school of thought, CEO duality, firm size, board sovereignty, and ownership structure have a constructive effect on firm performance. Other schools of thought differed, claiming that these variables actually harm firm performance.

In fact, Yermack (1996), along with Mashayekhi and Bazaz (2008) found the result of adverse relation of board size and firm performance of the firm. Whereas constructive result was found in the study by Abor (2007); Kiel and Nicholson (2003) when comparing board size and corporate performance. Some researchers also found no correlation between firm size and the performance of the firm in their studies (Mohd Ghazali, 2010).

In studies relating to independent directors and business performance, Jackling and Johl (2009); Mashayekhi and Bazaz (2008); Rosentein and Wyatt (1990) found that independent board members are related to firm performance; while Agrawal and Knoeber (1996) differed in their views. They stated that independent directors effectively harm firm performance. Interestingly, some other researchers found no relation of outside directors on the firm (Coles et al., 2001)

Abor (2007) believed that CEO duality harms a firm's profitability and performance; while Ehikioya (2009) stated that CEO duality has a positive relationship with both firm performance and profitability. Interestingly, Jackling and Johl (2009) found no relationship between CEO duality and firm performance.

Guo and Kumara (2012) tried to explore the procedures of corporate governance in the Columbian stock market. They found an inverse connection between firm performance and board size. The authors also noted that independent directors have a destructive relation with firm performance. 
Sami et al. (2011) found positive relations among board size and educational qualifications of directors with firm performance. Lam and Lee (2008) stated that different theories give different results, thus, suggested that there should be a mixture of both agency and stewardship theory to improve quality and performance relationship. They also found a favorable impact of CEO duality on non-family firms, but an adverse effect on family firms. Hermalin and Weisbach (1998) stated that board success relies on the structure of the board, while Ehikioya (2009) stated that there is no relationship between the structure of the board and business performance. Ujunwa (2012) recommended an inverse link between board size and firm performance. Li et al. (2008) recommended a beneficial link between outside directors and organizational performance. According to Eloumi and Gueyie (2001), firms suffering from financial crises are mostly found with few or no independent directors. Krivogorsky (2006) endorsed other studies, and stated that there's a positive relation of board independence with profitability ratios in European companies. Yermack (1996) insisted on the shaky relationship between the board size and performance; whereas Vafeas (1999) and Golden and Zajac (2001) forecasted that there's no link between firm performance and board size. Abdullah (2004) and Daily and Dalton (1992) also didn't find any link with the creation of the board vis a vis firm performance. Donaldson and Davis (1991); Brickley et al. (1997); and Coles et al. (2001) stated that board structure should consist of both independent and dependent directors. According to Ujunwa (2012), Nigerian firms have seemed to show a negative relation of firm performance with CEO duality; however, the author stated that if board size is small, then CEO duality provides a better impact on firm performance. Kang and Zardkoohi (2005) explained that CEO duality result compared with firm performance is still not sure and requires more research. Fama and Jenson (1983) stated that CEO duality is the cause of agency cost, as it gives equal chance to the CEO to keep control on the board's decisions, and an eye on the management. Laing and Weir (1999) found that CEO duality is unfavorable for investors' money, as more self-interest decisions are made in the dual role rather than maximize the shareholder's wealth.

There has been plenty of work done on investigating different corporate governance procedures and measuring firm performance; but the results are widely different. The only point that is common among all research is that the future of any organization is conditional to the successful implementation of corporate governance, and that is why Porfírio and Carrilho (2020) emphasized applying corporate governance to every firm.
Hence, this issue is still unresolved, especially for the firms of Pakistan. To resolve this dispute, we took sample of Pakistani listed firms and linked corporate governance and performance, expecting to obtain valuable findings, which would possibly improve the firm performance of listed companies of Pakistan.

\section{THEORETICAL FRAMEWORK}

Agency theory is one of the most popular academic frameworks that has led to the development of the AngloSaxon model of corporate governance. The model is widely used to help the board of directors for curbing excessive executive power in the hands of management (Pande and Ansari, 2014). The Agency Theory, Stakeholder Theory, Stewardship Theory, and Resource Dependency support our research, which aims to improve firm performance with the help of corporate governance instruments. Corporate governance has significant importance, especially in terms of examining the performance of the board of directors. As a result, theories that best explain the structure and reporting practices are being used for better understanding and increasing performance.

Corporate governance has been focused on the separate entity concept which results in a principal-agent problem. It is the view that the board of directors has a key responsibility to minimize any conflict between managers and business owners. The intention behind the theory is to minimize selfinterest and boost a firm's value by minimizing agency costs and implementing accounting procedures (Deegan, 2004). The agency problem is different in each country. In some countries, if investors are not satisfied with the performance of the management, they leave the organization, which in turn, results in a reduction in share price. In an opposing scenario, most shareholders are dominant on minority shareholders and the management, and thereby control them according to their needs (Spanos, 2005).

The Stakeholder theory was introduced by Milton Friedman (Dmytriyev et al., 2021); it expresses the significance between business and stakeholders, such as investors, employees, and customers. The stakeholder's philosophy is the expansion of the Agency theory, where the obligation of the board of directors is added from investors to other key participants attached to the business. According to the theory, increasing the shareholder's wealth is not only the priority of the firm's management, but also growth is essential. The theory also states that if policies are applied properly, it will cover all rights of shareholders and the business life cycle of the firm will be increased. 
Resource dependency theory explains that the inner structure of an organization needs to match with the external environment, which in turn, can be fulfilled by the board, its size, and competent board members. The theory states that the directors bring knowledge, talent, and different policies from the outside world to the organization for improving firm performance.

Stewardship theory considers managers as a good steward, who acts in the best interest of the organization. The concept is established on the behavior of executives. According to Smallman (2004), when investors' capital is boosted, management will get the reward as well. Stewardship theory considers the position of CEO and Chairman similar and as no need for non-executive directors as theory explains that all the individuals will be working in the favor of the organization.

Corporate governance covers the following practices:

- A1: Boards with CEO duality will have high performance

- A2: More the executive directors, better the performance of the company

- A3: Smaller boards have better performance

- A4: Young board member leads to better performance

- A5: Higher average education of board results in better performance

- A6: Similarity in the interest of board members and management results in better performance

- A7: Lower level of board independence leads to better results in performance.

The primary focus of corporate governance procedures is to understand how humans can be motivated to contribute to the achievement of organizational vision (Chrisman, 2019). According to Fan et al. (2011), corporate governance has two main models: 1. Anglo-American Model and the 2. German Model:

Anglo-American model's focus is on the management by a single board of directors; the purpose of this is to supervise and manage the firm (Floyd and Lane, 2000). This model is mostly used in the US, the UK, and Canada, among others. The board is designed from the executive directors who work as the manager of the company, whereas others are independent directors, who work as a supervisors, and bring external experience to the company. The German model on the other hand, is mostly used in Europe, such as in Germany, the Netherland, and Sweden (Fan et al., 2011); this model includes two-tier structures. It has a supervisory board as well as other boards. The supervisory board includes non-executive directors, while the board consists of managers. Clearly, as the name suggests, the supervisory board supervises the activities of the firm by directly managing the management that is included in the board.

As stated by Goergen et al. (2008), the other main difference between both models is that the Anglo-American model does not cover the stakeholders' interest in corporate governance, and non-executive directors do not have sufficient supremacy to take part in controls. On the other hand, in the German model, the interest of all stakeholders is taken care of, especially the banks, workers, and suppliers. To adopt the best corporate governance practice, both models can be combined and policy for the company can be adopted.

We adopted a quantitative approach, as we believed that it would help us find a link among the variables. Many studies in the past have used the regression test to check the procedures of corporate governance, and we will also use the same. Our study covers data from top 75 companies registered in the Pakistani stock market.

Selecting the top 75 companies in the sample of the total registered company of stock exchange is because it performs a significant role in GDP, and helps in generalizing the result, as most of these companies have been in the top position since 2005. We gathered information for corporate governance procedures from approved internet sites of the stock exchange, whereby the reports are disclosed, along with the corporate governance practice of all the enterprises. The record for the financial report is taken from Pakistan Stock Exchange (PSX) official website and shows the annual reports of all listed company registered in the Pakistani stock market.

We use a correlation test to measure the relationship between each assumption to see firm performance. The result would help in finding the direct and significant relation, whereas a regression run would help in predicting the stewardship policy practice in terms of firm performance.

\section{THE MODEL}

The model used for analysis is as follows:

$F P_{i t}=\alpha+\beta_{1} T D I R_{i t}+\beta_{2} I N D I R_{i t}+\beta_{3} E S T Y E A R_{i t}+\beta_{4} C E O D_{i t}+\beta_{5}$ $A V G E D_{i t}++u_{i t}$

Where:

$F P_{i t}=$ Firms performance is measured by return on asset (ROA) 
$\beta_{1} T D I R_{i t}=$ Total number of directors

$\beta_{2} I N D I R_{i t}=$ Board independence

$\beta_{3} E S T Y E A R_{i t}=$ Established years of firm

$\beta_{3} C E O D_{i t}=$ CEO duality

$\beta_{4} A V G E D_{i t}=$ Average education of board of directors

$u_{t}=$ Error term.

\section{DATA AND SAMPLE}

The data include the top 75 Pakistani organizations registered on PSX over the period 2010-2019. We collected data for total members of the board, board independence, CEO duality, average education of board members, and years of the establishment of the firm from the yearly reports of the firms available at the PSX database (Figure 1). The data include total assets, net income, leverage, and other financial variables covering 2010-2019. We divided the firms into five categories according to PSX. We manually collected board size, their independence, CEO dual role, education of board members, and year of establishment of each company. We retrieved these data from: (i) Financial website for securities (PSX.com), (ii) annual reports for 2010-2019, and (iii) Google and related search engines.

We used ROA as a dependent variable (Akhtar et al., 2020), and calculated it in the same method as has been done in previous studies (Parkinson, 1980). We calculated Return on equity by dividing net income with shareholder equity. The results show how much shareholders are earning vis a vis the investments they have made.

\section{FINDING AND ANALYSIS}

The summary of descriptive figures is shown in Table 2. Mean is the quantity of significant propensity. The evocative figures for the 75 firms (75 companies) were determined individually to relate firm performance.

The sample consisted of 75 firms registered in PSX from 2010 to 2019 , making 750 observations in total. The average ROA for the sample noted is $6.36 \%$. The average education and established year of the firm in the test have an average percentage of $1.19 \%$ and $1.54 \%$.

The result of Table 3 shows that variables certainly connected; therefore, multi-collinearity cannot be seen. The p-value of INDDIR, EST YEAR, and CEOD is less than or equal to 0.010 resulting in rejecting Ho and showing a bond between variables.
Table 4 shows the result of regression analysis. The establishment and implementation of board independence show a negative impact on ROA, whereas total directors and average education show a positive impact on ROA. In this model, a $10 \%$ increase in board independence will reduce the ROA by $36 \%$, whereas a $10 \%$ increase in total directors and average education of directors will increase ROA by $10 \%$ and $39 \%$, respectively. As CEO duality and established years of the firm give insignificant value, it means that EST YEAR and CEOD do not affect ROA. However, $32.7 \%\left(\mathrm{R}^{2}=0.32\right)$ shows that the model explains all the adaptability of the information around its mean and the values are acceptable in panel data.

In the studies by Ehikioya (2009), she recommends the inverse relation between CEO duality and performance of the firm, whereas Lam and Lee (2008) revealed in their research that years of establishment of the firm have a positive link with the performance but in our result for the

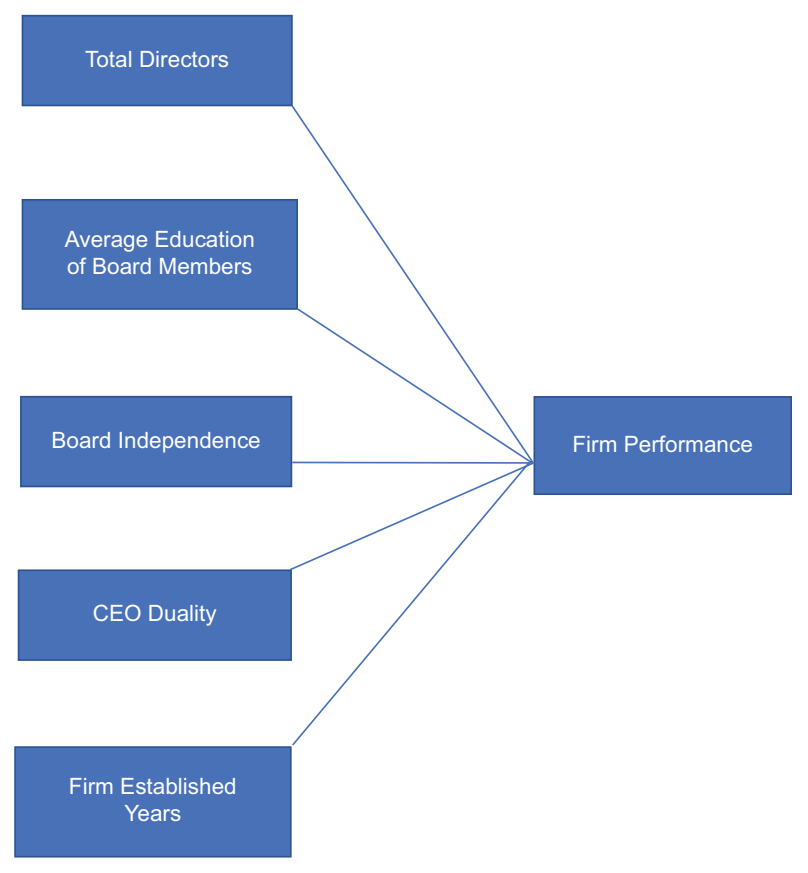

Figure 1: Impact of total directors, average education of board members, board independence, CEO duality, and firm establishment on the firm performance

\section{: Summary of research design}

\section{Research design}

\begin{tabular}{lll}
\hline 1 & The type of study & Explanatory study \\
2 & The method of data & Secondary source \\
3 & The purpose of study & Causal research \\
4 & The time dimension & Panel data \\
\hline
\end{tabular}


Ali, et al.: Impact of corporate governance

\begin{tabular}{|c|c|c|c|c|c|c|}
\hline & ROA & TDIR & INDDIR & EST YEAR & CEOD & AVGED \\
\hline Mean & 6.367441 & 0.900063 & 0.021368 & 1.548560 & 0.153333 & 1.197908 \\
\hline Median & 4.960000 & 0.903090 & 0.020408 & 1.580000 & 0.000000 & 1.197000 \\
\hline Maximum & 68.20000 & 1.146128 & 0.160000 & 1.851000 & 1.000000 & 1.334000 \\
\hline Minimum & -40.02000 & 0.698970 & 0.000000 & 0.301000 & 0.000000 & 1.079000 \\
\hline Std. Dev. & 12.06999 & 0.069740 & 0.019933 & 0.230492 & 0.360549 & 0.030121 \\
\hline Skewness & 0.596291 & 1.258765 & 1.974041 & -2.312266 & 1.924277 & 0.422760 \\
\hline Kurtosis & 5.682277 & 4.363297 & 9.536696 & 12.68558 & 4.702841 & 7.018919 \\
\hline Jarque-Bera & 269.2770 & 256.1419 & 1822.367 & 3599.897 & 553.4698 & 527.0817 \\
\hline Probability & 0.000000 & 0.000000 & 0.000000 & 0.000000 & 0.000000 & 0.000000 \\
\hline Sum & 4775.581 & 675.0475 & 16.02576 & 1161.420 & 115.0000 & 898.4310 \\
\hline Sum Sq. Dev. & $109,117.7$ & 3.642934 & 0.297596 & 39.79188 & 97.36667 & 0.679531 \\
\hline Observations & 750 & 750 & 750 & 750 & 750 & 750 \\
\hline & ROA & TDIR & INDDIR & EST YEAR & CEOD & AVGED \\
\hline $\mathrm{ROA}$ & 1.000000 & & & & & \\
\hline TDIR & 0.120454 & 1.000000 & & & & \\
\hline INDDIR & -0.021723 & -0.041845 & 1.000000 & & & \\
\hline EST YEAR & -0.081087 & -0.053836 & 0.150597 & 1.000000 & & \\
\hline CEOD & -0.061315 & -0.139979 & 0.017068 & 0.063646 & 1.000000 & \\
\hline AVGED & 0.153412 & 0.148553 & 0.155634 & -0.050596 & -0.011731 & 1.000000 \\
\hline
\end{tabular}

Table 4: Result of regression analysis

Dependent variable: ROA

Method: Panel least squares

Date: $10 / 25 / 21$

Time: 21:36

Sample: 20102019

Periods included: 10

Cross-sections included: 75

Total panel (balanced) observations: 750

\begin{tabular}{|c|c|c|c|c|}
\hline Variable & Coefficient & Std. error & t-Statistic & Prob. \\
\hline C & -48.88100 & 15.26688 & -3.201768 & 0.0014 \\
\hline TDIR & 10.26046 & 5.340334 & 1.921314 & 0.0551 \\
\hline INDDIR & -36.34014 & 18.75258 & -1.937874 & 0.0530 \\
\hline EST YEAR & -1.528253 & 1.605281 & -0.952016 & 0.3414 \\
\hline CEOD & -1.192693 & 1.019310 & -1.170098 & 0.2423 \\
\hline AVGED & 39.77355 & 12.42869 & 3.200141 & 0.0014 \\
\hline R-squared & 0.327046 & \multicolumn{2}{|c|}{ Mean dependent var } & 6.367441 \\
\hline Adjusted R-squared & 0.321611 & \multicolumn{2}{|c|}{ S.D. dependent var } & 12.06999 \\
\hline S.E. of regression & 9.941365 & \multicolumn{2}{|c|}{ Akaike info criterion } & 7.440575 \\
\hline Sum squared resid. & 73431.24 & \multicolumn{2}{|c|}{ Schwarz criterion } & 7.483696 \\
\hline Log likelihood & -2783.216 & \multicolumn{2}{|c|}{ Hannan-Quinn criteria } & 7.457191 \\
\hline F-statistic & 60.18115 & \multicolumn{2}{|c|}{ Durbin-Watson stat. } & 1.651846 \\
\hline Prob. (F-statistic) & 0.000000 & & & \\
\hline
\end{tabular}


Ali, et al.: Impact of corporate governance

\begin{tabular}{lllll} 
S. No. & Variables & Nature & Exp. relation & Symbol \\
\hline 1 & Return on assets & Dependent & & ROA \\
2 & Board independence & Independent & - & INDDIR \\
3 & Total board members & Independent & + & TDIR \\
4 & CEO duality & Independent & - & CEOD \\
5 & Average education of board members & Independent & + & AVGED \\
6 & Established years of firm & Independent & - & EST YEAR \\
\hline
\end{tabular}

period of 2010-2019 for top 75 companies of Pakistan, the result shows no relation and gives insignificant values.

Table 5 shows the establishment and implementation of board independence, the total number of directors, and their education have effects on ROA. It can be seen from the table of covariance analysis that all the independent variables other than CEOD and EST YEAR are affecting the dependent variable either inversely or positively.

The increase in board independence will affect the ROA negatively, hence meeting the standards for the corporate governance be followed in Pakistan. Moreover, the increase in total director and average education will affect ROA positively. CEO duality and established year of firm will not affect ROA. Hence, total directors and their education do have a big effect on the firm performance. Moreover, $32.7(\mathrm{R}$ square $=0.32)$ shows that the pattern describes the changes in the numbers around its mean. Many studies have tried to measure the firm performance by a different measure, but we tried to measure it by ROA. The statistical significance is $1 \%, 5 \%$, and $10 \%$. Moreover, our result shows significance at $5 \%$.

\section{CONCLUSION}

The study intended to assess the present state of corporate governance in Pakistan and to see if the corporate governance practice affects firm performance. Several hypotheses were tested using secondary data to find the corporate governance difference of the instruction by international corporate governance standard and the one followed in Pakistan. The first crucial remark is that we validate that corporate governance procedures do play role in the firm performance. Sharma and Irving (2005) have already discussed that procedures are a great tool for the success of the organization. "High commitment management policy" is related to corporate governance philosophy and promotes free exchange of ideas, workers equality, and the formation of confidence. Second, we have preferred using the Anglo-American model which consists of one line of the board of directors having executive and non-executive directors as well as further having two committees: Operational committee and control committee. Finally, after applying corporate governance procedures, we have found the relation between firm performance and independent variables which are board independence, the total number of directors, and their education. CEO duality and years of the establishment of the firm have not shown significance in the case of Pakistan.

It is found during research that board independence has a key role in the firm performance, and in most companies, the board independence is very low (Vieira, 2018). The main reason figured is that either most of the firms are family oriented in Pakistan and board independence is not taken seriously or the same board members are also part of the other committees which can be a conflict of interest. As the result shows that the more board independence is lost, the negative ROA will become. It can be proved from the result that a $10 \%$ change in board independence will move $36.3 \%$ positive ROA.

Earlier studies have revealed that average education performs a significant role in the success of the organization (Sheikh et al., 2018). The board leads the organization, and the more educated board member exists, the more modern way of communication will be transferred lower in the hierarchy. Our result shows that the average education of the board members affects firm performance and a 10\% change in executive compensation will affect $39.6 \%$ in ROA.

To wrap up the research, it can be concluded that board independence, the total board size, and the education of board members have a significant effect on the Pakistani firm's performance which can be measured by ROA, whereas CEO duality and established years of the firm have an insignificant effect on firm performance. Hence, it is suggested for the cooperate sector to more focus on board characteristics rather than CEO duality and its life. The formation, functionality, and operationalization of the board are key for corporate success. 


\section{AUTHORS' CONTRIBUTIONS}

Conceptualization, citation: Jawad Ahmed and Sabahat Nisar, data collection citation: Sabahat Nisar, formal analysis, citation: Amjad Ali, methodology, citation: Wajid Alim, writing - original draft, citation: Jawad Ahmed, and writing - review and editing, citation: Amjad Ali and Wajid Alim. All authors have read and agreed to the published version of the manuscript.

\section{ACKNOWLEDGMENTS}

I would like to express my special appreciation and thanks to my professor Dr. Amjad Ali, you have been a tremendous mentor for me. I would like to thank you for encouraging my research and for allowing me to grow as a research scientist. Your advice on both research as well as on my career have been invaluable. I would also like to thank my other members of research, Professor Dr. Wajid Alim and scholar Sabahat Nisar for injecting their efforts in the research. A special thanks to my family especially to my father. Words cannot express how grateful I am to him for supporting me in my life and giving me confidence for taking first step of my tasks. Your prayer for me was what sustained me thus far. I can't thank you enough for encouraging me throughout this experience. To my beloved daughter Mirha Hassan, I would like to express my thanks for being such a good girl always cheering me up. Finally, I thank my ALLAH, for letting me through all the difficulties. You are the one who let me finish my research. I will keep on trusting you for my future. Thank you, ALLAH.

\section{FUNDING}

This research received no specific grant from any funding agency in the public, commercial, or not-for-profit sectors. The cost of collecting data was incurred by the authors and was distributed equally among them.

\section{CONFLICTS OF INTEREST}

The authors have no conflicts of interest to declare. All coauthors have seen and agree with the contents of the manuscript and there is no financial interest to report. We certify that the submission is original work.

\section{REFERENCES}

Abdullah, S. N. (2004). Board composition, CEO duality and performance among Malaysian listed Companies. Corporate Governance, 4(4), 47-61.

Abor, J. (2007). Debt policy and performance of SMEs: Evidence from Ghanaian and South African firms. Journal of Risk Finance, 8(4), 364-379.

Agrawal, A., \& Knoeber, C. (1996). Firm performance and mechanisms to control agency problems between managers and shareholders. Journal of Financial and Quantitative Analysis, 31, 377-397.

Akhtar, S., Khan, T., \& Khan, P. A. (2020). Examine the key drivers affecting bottom line: A panel estimation study of Indian commercial bank. Journal of Critical Reviews, 7(9), 2020.

Brickley, J. A., Coles, J. L., \& Jarrell, G. (1997). Leadership structure: Separating the CEO and chairman of the board. Journal of corporate Finance, 3(3), 189-220.

Cadbury Committee. (1992). The Report of the Committee on the Financial Aspects of Corporate Governance, Cadbury Committee, London.

Casillas, J. C., \& Pastor, F. (2015). The Top 250 Multinational Family Firms, Chair of Santander Family Business, University of Seville, Spain.

Chan, A. W., \& Cheung, H. Y. (2012). Cultural dimensions, ethical sensitivity, and corporate governance. Journal of Business Ethics, 110(1), 45-59.

Chrisman, J. J. (2019). Stewardship theory: Realism, relevance and family governance. Entrepreneurship Theory and Practice, 43(3), 104225871983847.

Coles, J. W., McWilliams, V. B., \& Sen, N. (2001). An examination of the relationship of governance mechanisms to performance. Journal of Management, 27(1), 23-50.

Daily, C. M., \& Dalton, D. R. (1992). The relationship between governance structures and corporate performance in entrepreneurial firms. Journal of Business Venturing, 7(5), 375-386.

Daily, C. M., \& Dalton, D. R. (1997a). Separate, but not independent: Board leadership structure in large corporations. Corporate Governance, 5(3), 126-136.

Deegan, C. (2004), Financial Accounting Theory, McGrawHill Australia Pty Ltd, NSW, New York

Dmytriyev, S. D., Freeman, R. E., \& Hörisch, J. (2021). The relationship between stakeholder theory and corporate social responsibility: Differences, similarities, and implications for social issues in management. Journal of Management Studies, 58(6), 1441-1470.

Donaldson, L., \& Davis, J. H. (1991). Stewardship theory or agency theory? CEO governance and shareholder returns. Australian Journal of Management, 16(1), 
49-65.

Ehikioya, B. I. (2009). Corporate governance structure and firm performance in developing economies: Evidence from Nigeria. Corporate Governance, 9(3), 231-43.

Eloumi, F., \& Gueyie, J. P. (2001). Financial distress and corporate governance: An empirical analysis. International Journal of Business and Society, 1(1), 15-23.

Fama, E. F., \& Jensen, M. C. (1983), Separation of ownership and control. The Journal of Law and Economics, 26(2), 301-325.

Fan, J. P., Wei, K. J., \& Xu, X. (2011). Corporate finance and governance in emerging markets: A selective review and an agenda for future research. Journal of Corporate Finance, 17(2), 207-214.

Floyd, S. W., \& Lane, P. J. (2000). Strategising throughout the organisation: managing role conflict in strategic renewal. Academy of Management Review, 25(1), 154-177.

Goergen, M., Manjon, M. C., \& Renneboog, L. (2008). Is the German system of corporate governance converging towards the Anglo-American model? Journal of Management and Governance, 12(1), 37-71.

Golden, B. R., \& Zajac, E. J. (2001). When will boards influence strategy? Inclination $\times$ power $=$ strategic change. Strategic Management Journal, 22(12), 1087-1111.

Gompers, P. A., Ishii, J. L., \& Metrick, A. (2003). Corporate governance and equity prices. Quarterly Journal of Economics, 118(1), 107-155.

Gulzar, M., \& Wang, Z. (2010). Corporate governance and non-listed family owned businesses: An evidence from Pakistan. International Journal of Innovation, Management and Technology, 1(2), 124.

Guo, Z., \& Kumara, U. (2012). Corporate governance and firm performance of listed firms in Sri Lanka. Journal of Education, Society and Behavioural Science, 40, 664-667.

Hermalin, B. E., \& Weisbach, M. S. (1998). Endogenously chosen boards of directors and their monitoring of the CEO. American Economic Review, 88, 96-118.

Houcine, A., Zitouni, M., \& Srairi, S. (2021). The impact of corporate governance and IFRS on the relationship between financial reporting quality and investment efficiency in a continental accounting system. EuroMed Journal of Business, 96-108.

Hussain, S., \& Safdar, N. (2018). Tunneling: Evidence from family business groups of Pakistan. Business and Economic Review, 10(2), 97-121.

Jackling, B., \& Johl, S. (2009). Board structure and firm performance. Corporate Governance, 17(4), 492-509.

Jan, A. A., Lai, F. W., Draz, M. U., Tahir, M., Ali, S. E. A.,
Zahid, M., \& Shad, M. K. (2021). Integrating sustainability practices into islamic corporate governance for sustainable firm performance: From the lens of agency and stakeholder theories. Quality and Quantity, 1-24.

Kang, E.,\& Zardkoohi,A. (2005). Board leadership structure and firm performance. Corporate Governance, 13(6), 785-799.

Khan, P. A., \& Johl, S. K. (2019). Nexus of comprehensive green innovation, environmental management system-14001-2015 and firm performance. Cogent Business and Management, 6(1), 1691833.

Khan, P. A., \& Johl, S. K. (2020). Firm Performance from the Lens of Comprehensive Green Innovation and Environmental Management System ISO. Processes, 8(9), 1152.

Khan, P. A., Johl, S. K., \& Johl, S. K. (2021). Does adoption of ISO 56002-2019 and green innovation reporting enhance the firm sustainable development goal performance? An emerging paradigm. Business Strategy and the Environment, 30(7), 2922-2936.

Kiel, G. C., \& Nicholson, G. J. (2003). Board composition and corporate performance: How the Australian experience informs contrasting theories of corporate governance. Corporate Governance, 11(3), 189-205.

Krivogorsky, V. (2006). Ownership, board structure, and performance in continental Europe. The International Journal of Accounting, 41, 176-197.

Laing, D. \& Weir, C. M. (1999). Governance structures, size and corporate performance in UK Firms. Journal of Management Decision, 37(5), 457-464.

Lam, T. Y., \& Lee, S. K. (2008). CEO duality and firm performance: Evidence from Hong Kong. Corporate Governance, 8(3), 299-316.

Li, H. X., Wang, Z. J., \& Deng X. L. (2008). Ownership, independent directors, agency cost and financial distress: Evidence from Chinese listed companies. Corporate Governance, 8(5), 622-636.

Mashayekhi, B., \& Bazaz, M. S. (2008). Corporate governance and firm performance in Iran. Journal of Contemporary Accounting and Economics, 4(2), 156-172.

Miller, D., \& Breton-Miller, I. L. (2006). Family governance and firm performance: Agency, stewardship and capabilities. Family Business Review, 19(1), 73-87.

Mohd Ghazali, N. A. (2010), Ownership structure, corporate governance and corporate performance in Malaysia. International Journal of Commerce and Management, 20(2), 109-119.

Nandelstadh, V. A., \& Rosenberg, M. (2003). Corporate Governance Mechanisms and Firm Performance: Evidence from Finland. Helsinki: Working Papers, No. 497, Hanken School of Economics. 
Pande, S., \& Ansari, V. A. (2014). A theoretical framework for corporate governance. Indian Journal of Corporate Governance, 7(1), 56-72..

Parkinson, Michael. (1980). The Extreme Value Method for Estimating the Variance of the Rate of Return. The Journal of Business. 53. 61-65. 10.1086/296071.

Porfírio, J., Felício, J., \& Carrilho, T. (2020). Family business succession: Analysis of the drivers of success based on entrepreneurship theory. Journal of Business Research, 115, 250-257.

Rosentein, S., \& Wyatt, J. G. (1990). Outside directors, board independence, and shareholder wealth. Journal of Financial Economics, 26, 175-191.

Sami, H., Wang, J., \& Zhou, H. (2011). Corporate governance and operating performance of Chinese listed firms. Journal of International Accounting, Auditing and Taxation, 20, 106-114.

Shaheen, R., \& Nishat, M. (2005). Corporate Governance and Firm Performance an Exploratory Analysis. Paper Presented at Conference.

Sharma, P., \& Irving, P. (2005). Four bases of family business successor commitment: Antecedents and consequences. Entrepreneurship Theory and Practice, 29(1), 13-33.

Sheikh, M. F., Shah, S. Z. A., \& Akbar, S. (2018). Firm performance, corporate governance and executive compensation in Pakistan. Applied Economics, 50(18), 2012-2027.

Smallman, C. (2004). Exploring theoretical paradigms in corporate governance. International Journal of Business Governance and Ethics, 1(1), 78-94.
Spanos, L. J. (2005). Corporate governance in Greece: Developments and policy implcations. Corporate Governance, 5(1), 15-30.

Switzer, L. N., \& Tahaoglu, C. (2015). The benefits of international diversification: Market development, corporate governance, market cap, and structural change effects. International Review of Financial Analysis, 42, 76-97.

Toha, M., Johl, S. K., \& Khan, P. A. (2020). Firm's sustainability and societal development from the lens of fishbone eco-innovation: A moderating role of ISO 14001-2015 environmental management system. Processes, 8(9), 1152.

Ujunwa, A. (2012). Board characteristics and the financial performance of Nigerian quoted firms. Corporate Governance, 12(5), 656-674.

Vafeas, N. (1999). Board meeting frequency and firm performance. Journal of Financial Economics, 53, 113-142.

Vieira, E. S. (2018). Board of directors characteristics and performance in family firms and under the crisis. Corporate Governance, 18(1), 119-142.

Yermack, D. (1996). Higher market valuation of companies with a small board of directors. Journal of Financial Economics, 40, 185-211.

Zellweger, T. (2017). Managing the Family Business: Theory and Practice. Cheltenham, United Kingdom: Edward Elgar Publishing. 